\title{
Efficacy of Pomegranate (Punica granatum) Peel Extract Against Hymenolepis nana in infections Mice.
}

\author{
Wafa A. I. Al-Megrin \\ Department of Biology, Faculty of Science, Princess Nourah Bint Abdul Rahman University, Saudi Arabia. \\ http://dx.doi.org/10.13005/bbra/2010
}

(Received: 10 February 2016; accepted: 12 March 2016)

\begin{abstract}
To investigate the efficacy of pomegranate (Punica granatum) as an alternative and safe treatment against Hymenolipes nana through experimental study on the white laboratory mice. Twenty eight Swiss albino mice naturally infected with Hymenolipes nana. Animals were divided into four groups, one group as control and groups 2-4 were fed daily with dose $0.5 \mathrm{ml}, 1.0 \mathrm{ml}$ and $1.5 \mathrm{ml}$ pomegranate peel extract $(300 \mathrm{mg} / \mathrm{kg})$ respectively, The egg counts per gram (EPG) one day before treatment and on day 1, 7, 14, and 21 after treatment. All animals were then sacrificed under on day 21 . The content of intestines were examined for the presence of worms and counting. Results from current Study revealed that, pomegranate peel extract was lead to reduce the eggs output in fecal pellets of treated infected groups comparing with control group. In addition, the different doses $0.5 \mathrm{ml}, 1.0 \mathrm{ml}$ and $1.5 \mathrm{ml}$ of a pomegranate peel extract demonstrated a directly proportional reduction in EPG count $(31.5,38.6$ and 43.5$)$ respectively. On the other hand, the number of worms at necropsy was decreased (15.6 $\pm 2.6,8.4 \pm 2.1$ and $5.7 \pm 2.5)$ in treated infected groups $(0.5 \mathrm{ml}, 1.0 \mathrm{ml}$ and $1.5 \mathrm{ml})$ respectively. The findings of this study indicate that Pomegranate peel extract has active role to treat infection of $\mathrm{H}$. nana due to possesses potential anti-cestodal activity.
\end{abstract}

Key words: Pomegranate, Hymenolepis nana, Natural, Treatment.

Hymenolepis nana, generally known as the dwar tapeworm which is a globally widespread zoonosis disease. Also, it is one of the most common cause of cestode infections, commonly infects rodents as well as human beings ${ }^{1-3}$. Mostly, $H$. nana infection has a cosmopolitan distribution with the highest prevalence and heaviest parasite burden among children in warm, arid climates with poor sanitation conditions ${ }^{4,5}$. It is endemic in Asia, Southern and Eastern Europe, Central and South America, and Africa ${ }^{6}$. The infection can have an epidemiologically significant impact in family units because it is the tapeworm which can be transmitted directly from person to other and

\footnotetext{
* To whom all correspondence should be addressed. E-mail: wafa.megren@gmail.com
}

because auto reinfection may occur ${ }^{7,8}$. Even though $H$. nana infections are typically asymptomatic, related heavy infections can cause headaches, weakness, anorexia, abdominal pain, and diarrhea ${ }^{9}$ and $H$. nana infection can cause emaciation and diarrhea and may be life-threatening. The life cycle might be either direct (human acquired infection by take of food and water contaminated with eggs) or indirect (it employ arthropods as intermediate hosts $)^{10,11}$. Immunocompromised Hosts can be auto infected; eggs are produced, hatched and complete their life cycle within the intestine of a single host ${ }^{12}$.

Research study of the helminths is aiming to identify potential and drug gable targets through biochemical, biophysical, genomic, proteomic, in vivo and vitro experiments in animal models ${ }^{13}$. Therefore, in the last few years, they recommended to use of biological substance instead of chemicals in the dominate on parasites because of that these 
natural products have potency against different pathogens and mostly are safe to use $\mathrm{e}^{14,15}$. Moreover, chemotherapeutics costs billions of dollars yearly for control of parasites. On the other hand, many of them show resistance of many parasites., contribute constantly increasing doses, which led to higher costs, that cannot be paid by many countries worldwide ${ }^{16}$. According to the World Health Organization (WHO), around 80\% of the world's population relies on plant based medicines for their elementary health needs ${ }^{17}$. In this connection, traditional medicines which based mainly on plant provide a very rich and accessible source of health care to people who are living in developing countries ${ }^{18}$.

At present, about $80 \%$ of the drugs which used around the world produce from natural products or some derivatives inspired by natural precursors ${ }^{19}$. Consequently, plants form a very rich source of bioactive chemical compounds against many diseases ${ }^{20}$. Thier are many studies on the Several plant to test their anthelmintic efficacy ${ }^{21-24}$. Also, Semmler et $a l^{16}$ used Plant extracts as remedies against endo- and ectoparasites due to their biocidal effect. However, the effects of some plants against pests and parasites was reported by Schmahl et a ${ }^{25}$.

pomegranate Punica granatum L. (Punicaceae), latterly described as nature's power fruit, is a plant used in traditional medicine for the treatment of various diseases ${ }^{26}$ widespread in the Mediterranean region. In spite of many studies conducted to examine the efficacy of pomegranate treating diseases and microbial infections, much remains unknown about its effects on parasitic infections. Moreover, some studies have indicated that pomegranate has anti- nematoidal , anticestodia $^{14,27}$ and anti-protozoan activities ${ }^{28,29}$. Recent years, some studies reported that pomegranate peel is a promising treatment for Cryptosporidium parvum and it is an effective as anti-coccidial as well as anthelmintic induced that does not induce any side effects ${ }^{30,31}$.

\section{The aim of study}

The aim of this study is to determine the efficacy of pomegranate as an alternative and safe treatment against Hymenolipes nana through experimental study on the white laboratory mice. Materials and methods

\section{Preparation of the pomegranate peel extract}

P.granatum peels were obtained from fruit purchased from a local market. According to the method described by Abdel Moneim ${ }^{26}$ Pomegranate peel extract was prepared with slight modification. Air dried powder $(100 \mathrm{~g})$ of pomegranate peels was extracted by percolation with 70\% methanol at room temperature and kept at $4^{\circ} \mathrm{C}$ for $24 \mathrm{~h}$. Then, the extract was concentrated under reduced pressure (bath temperature $50^{\circ} \mathrm{C}$ ) and dried in a vacuum evaporator. The residue was dissolved in distilled water and used in present experiment ${ }^{31}$.

\section{Animals}

Twenty eight Swiss albino mice of aged 2 months and weight between 25-35 gm each, proven to be naturally infected with Hymenolipes nana ( by detection of eggs in fecal samples smeared on microscopic slides), were obtained from the animal facilities of King Saud University, Riyadh, Saudi Arabia. The mice were bred under specified pathogen-free conditions and fed with feed (P 684) of the General Organization for Grain Silos and Flour Mills production in Riyadh, Kingdom of Saudi Arabia. The approval from the Animal Ethics Committee was obtained.

\section{Experimental design}

Animals were divided into four groups, with seven animals in each group.

\section{Control groups}

One groups served as the control group which have animals infected with Hymenolipes nana untreated.

\section{Experimental group}

Three groups served as the experimental groups.

Groups 2-4 were fed daily by single oral gavage with dose $0.5 \mathrm{ml}, 1.0 \mathrm{ml}$ and $1.5 \mathrm{ml}$ pomegranate peel extract $(300 \mathrm{mg} / \mathrm{kg}$ ) respectively, for twenty one days throughout the experimental period. The dose and the route of injection were selected on the basis of the previous studies ${ }^{30}$.

\section{Parasitological Studies}

Fresh faecal samples of mice were collected from cages on a day (pre-treatment period) and on day 1, 7, 14, and 21 (post-treatment period). Fecal egg counts were estimated using a modified Mc Master technique, and counts were expressed as numbers of eggs per gram (EPG). All 
animals were then sacrificed under chloroform anesthesia on day 21 and their intestines were opened and washed with a physiologic solution. The content of intestines were examined under a binocular microscope for the presence of worms and counting. The efficacy of extract was estimated using the method which described previously ${ }^{32}$.

\section{Statistical analysis}

Results were reported as mean \pm SD for each group. Statistical analysis was performed with student's t-test using a Microsoft Excel 2010. All $\mathrm{P}<0.05$ was considered as significant for all statistical analysis in this study.

\section{RESULTS}

The present study was constructed to evaluate the effect of a pomegranate peel extract against $H$. nana in mice. The results displayed in table 1 showing the effects of treatment with a pomegranate peel extract on the number of eggs passed in faeces. It is shown that pomegranate peel extract was lead to reduce the eggs output in fecal pellets of treated infected groups comparing with control group. In addition, the different doses $0.5 \mathrm{ml}, 1.0 \mathrm{ml}$ and $1.5 \mathrm{ml}$ of a pomegranate peel extract demonstrated a directly proportional reduction in EPG count (31.5, 38.6 and 43.5) respectively. On the other hand, the number of worms at necropsy was decreased (15.6 $\pm 2.6,8.4$ \pm 2.1 and $5.7 \pm 2.5)$ in treated infected groups $(0.5 \mathrm{ml}$, $1.0 \mathrm{ml}$ and $1.5 \mathrm{ml}$ ) respectively.

\section{DISCUSSION}

At recently years, several in vivo researches have been done to find new natural compounds which treat cestoda infections. The natural products were used to explore their antiparasitic prospective effects. Moreover, there are many recently studies which recorded the positive effect of several natural products against H. nana such as Carica papaya seeds ${ }^{33}$, Zingiber officinale ${ }^{34}$, Artemisia abrotanum and Salvia officinalis ${ }^{35}$ and Coriandrum sativum seeds ${ }^{36}$.

In this study, Pomegranate peel extract were used as treatment to $H$. nana infection in mice. Pomegranate peel extract has anthelmintic, anti-coccidial and antibacterial efficacy ${ }^{31,37}$. In addition, the stem barks and root are reported to have tonic and anthelmintic efficacy ${ }^{38}$. Many studies have demonstrated that the therapeutic

Table 1. Effects of a pomegranate peel extract against Hymenolipes nana in mice in different groups.

\begin{tabular}{lcccc}
\hline Groups & \multicolumn{2}{c}{ EPG count (mean \pm SD) } \\
(pre-treatment period) & $\begin{array}{c}\text { (\%) reduction } \\
\text { (post-treatment period) } \\
\text { (day1, 7, 14, \& 21) }\end{array}$ & $\begin{array}{c}\text { No. of worms at } \\
\text { post-treatment }\end{array}$ & $\begin{array}{c}\text { necropsy } \\
\text { (mean } \pm \text { SD) }\end{array}$ \\
\hline Control (untreated) & $560.7 \pm 25.3$ & $553.2 \pm 14.1$ & 1.34 & $25.1 \pm 2.2$ \\
P.granatum $(0.5 \mathrm{ml})$ & $571 \pm 73.7$ & $391.1 \pm 105.4$ & 31.5 & $15.6 \pm 2.6$ \\
P.granatum $(1 \mathrm{ml})$ & $538.3 \pm 31.4$ & $330.25 \pm 118.5^{*}$ & 38.6 & $8.4 \pm 2.1$ \\
P.granatum $(1.5 \mathrm{ml})$ & $605.3 \pm 61.2$ & $341.8 \pm 173.3$ & 43.5 & $5.7 \pm 2.5$ \\
\hline
\end{tabular}

* $\mathrm{P}<0.05$ compared with control group (t test)

antimicrobial, antioxidant and anti-inflammatory effects of $P$. granatum fruit, juice, and peel. These effects are mostly exerted by molecules such as tannins and polyphenols ${ }^{39-41}$. Furthermore, some of local recent researches were reported that Pomegranate demonstrate a significant anticoccidial as well as anthelmintic activity ${ }^{31}$ and it is a promising anti-coccidial therapeutic treatment ${ }^{30}$.

On the other hand, El-Sherbiny and ElSherbiny ${ }^{42}$ found that $P$. granate extract showed that $100 \%$ efficacy on Trichomonas vaginalis in vitro. Also, Ali et al. ${ }^{43}$ were confirmed the traditional use of rind of Punica granatum as anthelmintic against Raillietina spiralis and Ascaridia galli. Moreover, Hafiz et al. ${ }^{44}$ were indicated that pomegranate could be used as a hepatoprotective agent against $P$. chabaudi induced hepatic injury.

Our finding which demonstrate that Pomegranate peel extract has ability to effect on $H$. nana which lead to reduce output of eggs during treatment period in infection mice. The efficacy of Punica granatum with doses of $0.5 \mathrm{ml}, 1.0 \mathrm{ml}$ and 
$1.5 \mathrm{ml}$ reached (31.5, 38.6 and 43.5) respectively. Moreover, it decreased the number of worms at necropsy from $25.1 \pm 2.2$ in control group to 15.6 $\pm 2.6,8.4 \pm 2.1$ and $5.7 \pm 2.5$ in treated groups respectively. The efficacy of Punica granatum in present study is in agreement with other studies $[30,31,42,44,45]$ that showed the efficacy of Punica granatum as anthelmintic and anti-coccidial. Furthermore, the findings of current study are in agreement with other related studies which demonstrate the efficacy of different extract of natural products on $H$. nana ${ }^{33-36}$.

\section{CONCLUSION}

The findings of this study indicated that Pomegranate peel extract has active role to treat infection of $H$. nana due to possesses potential anti-cestodal activity.

\section{REFERENCES}

1. Castillo R, Grados P, Carcamo C, Miranda E, Montenegro T, Guevara A, et al. Effect of treatment on serum antibody to Hymenolepis nana detected by enzyme-linked immunosorbent assay. J Clin Microbiol 1991; 29: 413e4.

2. Bhagwant S. Diminished immune responsiveness in aged mice to Hymenolepis nana (Cestoda) tissue phase infection. Res $J$ 1999; 4: 9e23.

3. Sadaf H, Khan S, Kanwal N, Tasawer B, Ajmal $\mathrm{S}$. A review on diarrhoea causing Hymenolepis nana-dwarf tapeworm. Inter Res J Pharm 2013; 4: 32e5.

4. World Health Organization [WHO]. WHO model prescribing information: drugs used in parasitic diseases. 2nd ed 1995. Geneva.

5. Schantz P. Tapeworms (Cestodiasis). Gastroenterol Clin North Am 2006; 25: 637e53.

6. Fan P. Infectivity and development of the human strain of Hymenolepis nana in ICR mice. Southeast Asian J Trop Med Public Health 2005; 36: 97e102.

7. Maggi P, Brandonisio O, Carito V, Bellacosa C, Epifani G, Pastore G. Hymenolepis nana parasites in adopted children. Clin Infect Dis 2005; 41: 571e2.

8. Goswami R, Singh S, Kataria M, Somvanshi R. Clinicopathological studies on spontaneous Hymenolepis diminuta infection in wild and laboratory rats. Braz J Vet Pathol 2011; 4: $103 \mathrm{e} 11$.
9. Sirivichayakul, C, Radomyos, P, Praevanit, R, Pojjaroen-Anant, C, Wisetsing, P. Hymenolepis nana infection in Thai children. J Med Assoc Thai 2000; 83: 1035-1038.

10. Tasawar Z, Gul S, Bhutta M, Arif M. Prevalence of Hymenolepis nana in human beings in and around Multan-Pakistan. Pak J Life Soc Sci 2004; 2: $62 \mathrm{e} 4$

11. Gonenc, B. Analysis of the crude antigen of Hymenolepis nana from mice by SDS-PAGE and the determination of specific antigens in protein structure by western blotting. Turk $J$ Vet Anim Sci 2002; 26:1067e71.

12. Muzamil Mahdi Abdel Hamid, Ibrahim A. Eljack, Mohammad Khatim M. Osman, Arwa Hassan Elaagip, Mohamed S. Muneer. The prevalence of Hymenolepis nana among preschool children of displacement communities in Khartoum state, Sudan: A cross-sectional study. Travel Medicine and Infectious Disease 2015; 13(2) : 172-177.

13. Rana AK, Misra-Bhattacharya S. Current drug targets for helminthic diseases. Parasitol Res 2013; 112(5):1819-1831. DOI:10.1007/s00436013-3383-6

14. Abdel-Ghaffar F, Semmler M, Al-Rasheid KA, Strassen B, Fischer K, Aksu G, Klimpel S, Mehlhorn H. The effects of different plant extracts on intestinal cestodes and on trematodes. Parasitol Res 2011; 108(4):979-984. DOI:10.1007/s00436-010-2167-5

15. Bashtar AR, Hassanein M, Abdel-Ghaffar F, AlRasheid K, Hassan S, Mehlhorn H, Al-Mahdi M, Morsy K, Al-Ghamdi A. Studies on monieziasis of sheep I. Prevalence and antihelminthic effects of some plant extracts, a light and electron microscopic study. Parasitol Res 2011; 108(1):177-186. DOI:10.1007/ s00436-010-2060-2

16. Semmler M, Abdel-Ghaffar F, Al-Rasheid K, Mehlhorn H. Nature helps: from research to products against blood-sucking arthropods. Parasitol Res 2009; 105(6):1483-1487. DOI:10.1007/s00436-009-1634-3

17. WHO. Promoting the role of traditional medicine in health systems: a strategy for the African region. Report of the Regional Director.2000; AFR/RC50/9, p 5

18. WHO. WHO traditional medicine Strategy 2002-2005. WHO/ EDM/TRM/2002.1

19. Li JW, Vederas JC. Drug discovery and natural products: end of an era or an endless frontier? Science 2009; 325:161-165

20. Newman DJ, Cragg GM. Natural products as sources of new drugs over the last 25 years. $J$ Nat Prod 2007; 70:461-477

21. Ferraz ABF, Balbino JM, Zini CA, Ribeiro VL, 
Bordignon SA, von Poser G. Acaricidal activity and chemical composition of the essential oil from three Piper species. Parasitol Res 2010; 107(1):243-248. DOI:10.1007/s00436-0101878-y

22. Magalhães LG, Kapadia GJ, da Silva Tonuci LR, Caixeta SC, Parreira NA, Rodrigues V, Da Silva Filho AA. In vitro schistosomicidal effects of some phloroglucinol derivatives from Dryopteris species against Schistosoma mansoni adult worms. Parasitol Res 2010; 106(2):395401. DOI:10.1007/s00436- 009-1674-8

23. Elango G, Rahuman AA. Evaluation of medicinal plant extracts against ticks and fluke. Parasitol Res 2011; 108(3):513-519. DOI:10. 1007/ s00436-010-2090-9

24. Wu ZF, Zhu B, Wang Y, Lu C, Wang GX. In vivo evaluation of anthelmintic potential of medicinal plant extracts against Dactylogyrus intermedius (Monogenea) in goldfish (Carassius auratus). Parasitol Res 2011; 108(6):1557-1563. DOI:10.1007/s00436-010-2211-5

25. Schmahl G, Al-Rasheid KA, Abdel-Ghaffar F, Klimpel S, Mehlhorn H. The efficacy of neem seed extracts (Tre-san ${ }^{\circledR}$, MiteStop ${ }^{\circledR}$ ) on a broad spectrum of pests and parasites. Parasitol Res 2010; 107(2):261-269. DOI:10.1007/s00436010-1915-X

26. Abdel Moneim AE. Evaluating the potential role of pomegranate peel in aluminum-induced oxidative stress and histopathological alterations in brain of female rats. Biol Trace Elem Res 2012; 150:328-336. DOI: 10.1007/s12011-012-94982. PMID: 22945624

27. Fernandes RM, Rodrigues MLA, Borba HR, Fernandes MZCM and de Amorim A. Ausência da atividade anti-helmíntica de plantas em frangos de corte naturalmente infectados com Heterakis gallinarum (Schranck,1788) Madsen, 1949. Cienc Rural 2004; 34:1629-1682

28. Calzada F, Yepez-Mulia L and Aguilar A. In vitro susceptibility of Entamoeba histolytica and Giardia lamblia to plants used in Mexican traditional medicine for the treatment of gastrointestinal disorders. J Ethnopharmacol 2006; 108:367-370. PMID: 16846708

29. Dell’Agli M, Galli G, Corbett Y, Taramelli D, Lucantoni L, Habluetzel A, Maschi O, Caruso D, Giavarini F, Romeo S, Bhattacharya D and Bosisio E. Antiplasmodial activity of Punica granatumL. fruit rind. J Ethno pharmacol 2009; 125:279-285. DOI: 10.1016/j.jep.2009.06.025. PMID: 19577622

30. Al-Mathal EM and Alsalem AM. Pomegranate (Punica granatum) peel is effective in a murine model of experimental Cryptosporidium parvum. Exp Parasitol 2012; 131: 350-357. DOI: 10.1016/j.exppara.2013.05.004. PMID: 23684569

31. Dkhil, Mohammed A. Anti-coccidial, anthelmintic and antioxidant activities of pomegranate (Punica granatum) peel extract. Parasitol Res 2013; 112: 2639-2646. DOI: 10.1007/s00436-013-3430-3. PMID: 23609599

32. Hackova G and Velenby S. Parasitic Helminths of Humans and Animals: Health Impact and Control. Pharmacological Potential of Selected Natural Compounds in the Control of Parasitic Diseases. Springer, Vienna 2013; 29-99.

33. Abou Shady Omayma M., Maha M.A. Basyoni, Olfat A. Mahdy and Nardden Zakka Bocktor. The effect of praziquantel and Carica papaya seeds on Hymenolepis nana infection in mice using scanning electron microscope. Parasitol Res 2014; 113:2827-2836. DOI 10.1007/ s00436-014-3943-4

34. Lin Rong-Jyh, Chung-Yi Chen, Chin-Mei Lu, Yi-Hsuan Ma, Li-Yu Chung, Jiun-Jye Wang, June-Der Lee, Chuan-Min Yen. Anthelmintic constituents from ginger (Zingiber officinale) against Hymenolepis nana. Acta Tropica 2014;140 : 50-60. DOI:10.1016/ j.actatropica.2014.07.009

35. Amirmohammadi M, Khajoenia S, Bahmani M, Rafieian-Kopaei M, Eftekhari Z, Qorbani M. In vivo evaluation of antiparasitic effects of Artemisia abrotanum and Salvia officinalis extracts on Syphacia obvelata, Aspiculoris tetrapetra and Hymenolepis nana parasites. Asian Pac J Trop Dis 2014; 4(1): S250-S254.

36. Hosseinzadeh S, Maryam Jamshidian Ghalesefidi, Mehdi Azami, Mohammad Ali Mohaghegh, Seyed Hossein Hejazi, Mohsen Ghomashlooyan. In vitro and in vivo anthelmintic activity of seed extract of Coriandrum sativum compared to Niclosamid against Hymenolepis nana infection. J Parasit Dis 2015; 1-4. DOI.org/10.1007/s12639-0150676-y

37. Khan AJ, Hanee S. Antibacterial properties of Punica granatum peels. Int J Appl Biol Pharm Technol 2011; 2(3): 23-27.

38. Braga LC, Shupp JW, Cumings C, Jett M, Takahashi JA, Carmo I, et al. Pomegranate extract inhibits Staphylococcus aureus growth and subsequent enterotoxin production. $J$ Ethnopharmacol 2005; 96(1-2): 335-339.

39. Kadi H, Moussaoui A, Benmehdi H, Lazouni HA, Benayahia A, Nahal bouderba N. Antibacterial activity of ethanolic and aqueous extracts of Punica granatum L. bark. J Appl Pharmaceut Sci 2011; 01(10): 180-182. 
40. Cerda B, Llorach R, Ceron J, Espin JC, TomasBarberan FA. Evaluation of the bioavailability and metabolism in the rat of punicalagin, an antioxidant polyphenol from pomegranate juice. Eur J Nutr 2003; 42(1): 18-28.

41. Gracious RR, Selvasubramanian S, Jayasundar S. Immunomodulatory activity of Punica granatum in rabbits-a preliminary study. $J$ Ethnopharmacol 2001; 78(1): 85-87.

42. El-Sherbiny GM and El Sherbiny ET. The Effect of Commiphora molmol (Myrrh) in Treatment of Trichomoniasis vaginalis infection. Iran Red Crescent Med J 2011;13(7):480-486.

43. Ali N, Jamil A, Shah SW, Shah I, Ahmed G, Junaid M, Ahmed Z. Parasiticidal and brine shrimp cytotoxicity potential of crude methanolic extract of rind of Punica granatum Linn against round worms and tape worms. Pak J Pharm Sci 2015; 28(3):959-62 PMID: 26004729

44. Hafiz TA, Mubaraki MA, Al-Quraishy S, Dkhil MA. The potential role of Punica granatum treatment on murine malaria-induced hepatic injury and oxidative stress. Parasitol Res 2015;17. DOI 10.1007/s00436-015-4876-2

45. Labsi M, Khelifi L, Mezioug D, Soufli I, TouilBoukoffa C, Antihydatic and immunomodulatory effects of Punica granatum peel aqueous extract in a murine model of echinococcosis, Asian Pacific Journal of Tropical Medicine 2016; DOI: 10.1016/ j.apjtm.2016.01.038. (In press). 